\title{
20. The Tauroctony and Artaud's The Cenci: Back To The Ritual Drama
}

Onur EKLER 1

APA: Ekler, O. (2021) The Tauroctony and Artaud's The Cenci: Back To The Ritual Drama. RumeliDE Dil ve Edebiyat Araştırmaları Dergisi, (Ö9), 244-251. DOI: 10.29000/rumelide.981543.

\begin{abstract}
The Tauroctony, commonly known as the bull-slaying cult can be regarded as the manifestation of the anima mundi, or the life-giving and taking energy (libido-thanatos) in the Jungian psychology. The symbolical significance of this cult is essential to see the totality of life in the natural circulation of the anima mundi. Artaud in Theatre and Its Double argues that the natural cycle of the unbridled energy has long been disrupted in the Western society since the Western civilization has cut the organic ties with the nature and has infected itself with the worn-out institutions in the grip of the poisonous, hegemonic language with its totalizing principles. He asserts that an uncontrollable plague has struck Europe due to the infection in the language. However, interestingly enough, he takes a positive stance towards the uncontrollable plague. He sees the potential procreation in the destructive power of this plague that would eventually melt the decomposed organs in the society. Thanks to this, the flattened body of the society cleansed of the rotten institutions will cure itself back to its original cycle. Artaud justifiably asserts that the plague best manifests itself in its double: In theatre. The corrosive effect of the language is best observed in the Western theatre. Artaud sees the plague as an opportunity to restore it back to its ritual roots. He develops a new form of theatre, "the Theatre of Cruelty" to cleanse the infected body of the Western society. In this context, this study aims to explore the cleansing mission of Artaud's Theatre of Cruelty by corroborating the discussion with a detailed study on his notable play, Cenci.
\end{abstract}

Keywords: Cruelty, theatre, infection, tragedy, ritual

\section{The Tauroctony ve Cenci: Ritüel Dramaya Dönüş}

Öz

Kurban ritüeli olarak bilinen Tauroctony, Jung'un psikolojik yaklaşımında öne sürdüğü anima-mundi başka bir deyişle, yaşam enerjisinin (libido-thanatos) bir dışa vurumu olarak kabul edilebilir. Bu kültün sembolik önemi, evrenin ruhunun doğal akışında yaşamın bütünlüğünü görmek adına önem arz eder. Artaud, "The Theater and Its Double" adlı eserinde Batı medeniyetinin doğayla organik bağlarını koparması ve kendini baskın dilin totaliter ilkelerinin yörüngesindeki aşınmış kurumlarıyla zehirlemiş olmasından dolayı Batı toplumunda çok uzun zamandır organik enerjinin doğal seyrinin önü kesilmiş olduğunu belirtir. Artaud, dilin enfekte olmasından dolayı kontrolden çıkmış bir salgının Avrupa'yı çok sert vurduğunu ileri sürer. Buna rağmen, ilginçtir ki, Artaud salgına karşı olumlu bir tutum sergiler. O, toplumdaki çürümüş organları eritecek olan salgının yıkıcı gücündeki yaratıcı potansiyeli görür. Bu yaratıcı güç sayesinde, çürümüş yapılarından arınmış olan toplum orijinal döngüsüne geri dönecektir. Artaud, salgının kendini en iyi gösterdiği yerin tiyatro olduğunu haklı olarak öne sürer. Dilin aşındırıcı etkisi, en iyi Batı tiyatrosunda gözlemlenir. Artaud, bu salgın havasını toplumu yeniden ritüelliktik köklerine bağlamak için bir fırsat olarak görür. Bunun için, Batı toplumunun enfekte olmuş vücudunu arındırmak için "Şiddet Tiyatrosu" adında yeni bir tiyatro akımı başlatır. Bu bağlamda, bu çalışma,

Öğr. Gör. Dr., Mustafa Kemal Üniversitesi, Yabancı Diller Yüksekokulu, (Hatay, Türkiye). onurekler@gmail.com, ORCID ID: 0000-0002-0750-0417. [Araştırma makalesi, Makale kayıt tarihi: 18.07.2021-kabul tarihi: 20.08.2021; DOI: 10.29000/rumelide.981543]

RumeliDE Dil ve Edebiyat Araştırmaları Dergisi Osmanağa Mahallesi, Mürver Çiçeği Sokak, No:14/8 Kadıköy - ISTANBUL / TÜRKIYE 34714 e-posta: editor@rumelide.com tel: +90 $5057958124,+902167730616$
Address

RumeliDE Journal of Language and Literature Studies Osmanağa Mahallesi, Mürver Çiçeği Sokak, No:14/8

Kadıköy - ISTANBUL / TURKEY 34714

e-mail: editor@rumelide.com

phone: +90 505 7958124, +90 2167730616 
Artaud'un “Cenci” adlı meşhur eseri üzerine detaylı bir araştırma yaparak Şiddet Tiyatrosu'nun arındırıcı misyonunu keşfetmeyi amaçlar.

Anahtar kelimeler: Şiddet, tiyatro, enfeksiyon, tragedya, ritüel

\section{The Tauroctony and Artaud's The Cenci: Back To The Ritual Drama}

\section{Introduction}

Tauroctony or the bull-slaying cult depicts a sacrificial ritual that symbolically portrays the free-flowing energy in the universe. The energy with no predetermined course manifests itself in the spurt blood of the animal lying on a piece of earth that is sacrificed for the sake of Mithras, a mystic God in Roman mythology. What is quite striking in the cult is to see the unifying aspect of the spurt blood between the material and the metaphysical realms. The magnetic field of the energy as a creative and obliterating force sustains a sort of equilibrium between life and death. Therefore, the energy cycle between matter and spiritual in the sacrificial act, however cruel the act seems, brings on the organic creation, which, according to Artaud, has long been disrupted in the Western society. Artaud argues that in the Western society, the free course of energy found in the ancient ritualistic communities has been blocked or canalized into the predetermined paths, the boundaries of which have been drawn by the controlling mechanisms. In his masterpiece work, The Theatre and Its Double (1938), Artaud speaks of his unrest of the centripetal flow of the energy in the seemingly civilized West, particularly featuring its poisonous impact on the society. He asserts that the source of the infection is the hegemonic language with its totalizing principles though it does not reveal any symptoms. Concordantly, the institutions in the orbit of the logos-centric life get much infected and begin to wear away. Therefore, the plague for him is everywhere. However, surprisingly enough, he takes a positive stance towards the uncontrollable plague. He sees the potential procreation in the destructive power of this plague that would eventually melt the decomposed organs in the society. Thanks to this, the flattened body of the society cleansed of the rotten institutions will cure itself back to its original cycle. Artaud justifiably asserts that the plague best manifests itself in its double: In theatre. The corrosive effect of the language is best observed in the Western theatre. Artaud sees the plague as an opportunity to restore it back to its ritual roots. He develops a new form of theatre, the Theatre of Cruelty to cleanse the infected body of the Western society. In this context, this study aims to explore the cleansing mission of Artaud's Theatre of Cruelty by corroborating the discussion with a detailed analysis of his notable play, The Cenci.

\section{The Tauroctony and Artaud's The Cenci: Back To The Ritual Drama}

The most terrible plague for Artaud is the one that comes with "a silent rage" (Artaud, 1958: 20). He states that it tends to affect the very organs of the body. The dead bodies struck by such a sinister plague look unblemished. However, the controlling organs begin to be rotten internally. Artaud uses this analogy to explain the worn-out organs of the state that must be overthrown. He says; "once the plague is established in a city, the regular forms collapse (22). The state cannot function in the same structural order since the controlling organs fail to regulate the energy. Consequently, the unbridled energy "previously held in servitude and unavailable to reality, [...], sets loose in the guise of incredible images" (22), and causes anarchy which is not desirable in the hegemonic states. The reiterating point in Artaud's argument is how the institutions have paralyzed the organic life. The abandonment of the organs in the body-state renders the flux of forms, which in turn "will give freedom of the city and of existence the acts that are by nature hostile to the life of societies" (28).

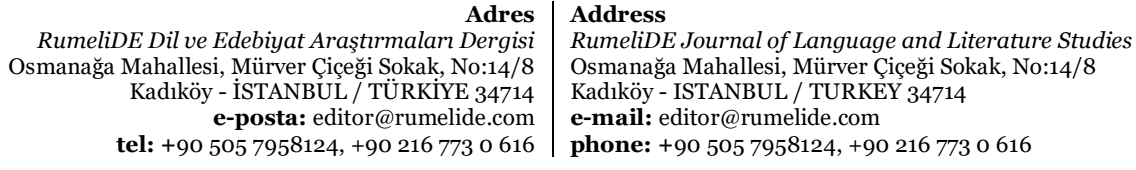


As a keen observer, Artaud turns the plague-struck state into an opportunity to put his notion of "body without organs" into practice. In this respect, theatre for him is crucial since it bears certain characteristics with the plague. Like the plague, theatre for Artaud, as in Augustine's metaphorical definition, is a fatal scourge "that attacks not bodies but customs" (26). He further claims that theatre strikes the slumbering minds with the purpose of invigorating the "dormant conflicts" in the western society (27):

Perhaps the theater's poison, injected into the social body, disintegrates it, as Saint Augustine says, but at least it does so as a plague, as an avenging scourge, a redeeming epidemic...(31)

The theather for Artaud establishes the ultimate equilibrium that is only sustained with obliteration. He asserts that the obliterating force charms the audience to a delirium state that will eventually "exalt the energies" necessary for cleansing of the body/state (31). Therefore, Artaud claims that theatre like plague is "beneficial" (31).

Artaud finds the healing power to redeem the theatre from the poisonous logos-centrism in the Balinese performance that he saw at the Paris International Colonial Exposition in 1931. Artaud is quite fascinated by the theatricality of the performance. As Clancy (1985) mentions in her article, "Artaud and the Balinese Theatre", what Artaud sees at this performance is the organic drama of "movement and gesture" that enables the coexistence of the divine and material realms previously found in the ancient rites (397). To Artaud, the Balinese theatre is an ideal example of what the theatre should be like. He wrote three articles on the Balinese theatre which would later become the part of his work, The Theatre and Its Double. Artaud (1958) argues that the organic flow of the energy that can be found in the Balinese theatre will help to "restore the [western] theatre, [...], [back] to its original destiny which it presents as a combination of [gestus, mimes, music, and the spectacle] fused together in a perspective of hallucination and fear" (53). Clancy (1985) particularly draws attention to the key elements in the Balinese theatre which shapes Artaud's vision as he frames his Theatre of Cruelty. She refers to the harmonious relation among "movement, articulation and music" that essentially attracts Artaud (399). For Artaud (1958), the actors like the Balinese dancers should resemble to "the animated hieroglyphs" that can express "some dark prodigious reality" used at a time before the hegemonic language (written or spoken) (44). If they are able to do so, they can freely play the signs, the gestures which have, according to Artaud, completely been repressed in the western theatre. The western theatre is a dissociated theatre devoid of shadows (12). It reduces the boundless possibilities down to the abstract words. However, the true theatre for Artaud (1958) has its language in space or "the veritable hieroglyphs" ("language of sounds, cries, lights, onomatopoeia") that may create "an anarchistic destruction" $(90,92)$. This will further create an organic state where the free association of forms will bring forth the totality of man.

Artaud further discusses that the true theatre generates new shadows as well as getting rid of the false ones. These shadows do not have any boundaries or limitations. With the appropriate mode of expression including "gestures, sounds, words, screams, light, darkness" they brutalize the forms making way for "the true spectacle of life" (Artaud, 1958: 12).

Thus, as Artaud reiterates in his seminal articles, the true awakening for the Western theatre lies in the magical performance of the Balinese theatre since its incarnational elements such as vibrant sounds, costumes, music, dance blurs the boundaries between the material and the transcendental by drawing the audience to a hypnotic state. Palermo (2007) in her Doctoral study on "Balinese Topeng" draws attention to the dualistic vision of life in the Balinese-Hindu philosophy. She refers to the dynamic relationship between the sekala (visible, earthly) and the niskala (invisible, transcendental) (51). As Artaud asserts, the dynamic interplay between the sekala and the niskala is what is needed in the Occidental theatre. Artaud

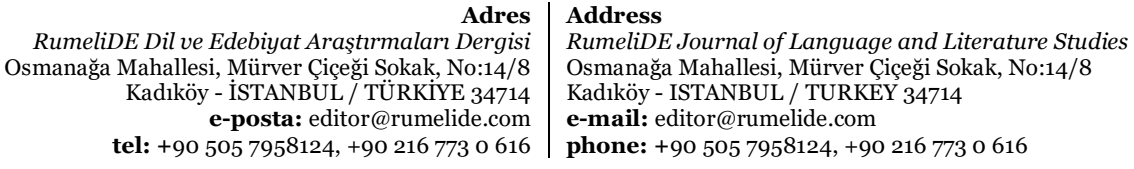


blames the Western theatre for the breakdown of such an organic dynamism as it creates the false image of reality. For Artaud (1958), it only reflects the surface reality which is reduced to "a mere inert replica" (48). However, Artaud states that there is another dimension of reality which is "archetypical and dangerous" beyond the surface. He metaphorically compares its principles to the dolphins which, "once they have shown their heads, hurry to dive back into the obscurity of the deep" (Artaud, 1958: 48). The theatre for Artaud should be a borderline where the realities from deep and shallow waters may coalesce into one with the sudden, immediate and shocking moves. According to Artaud, the ideal fusion of the sekala and the niskala can best be epitomized with the painting, The Daughters of Lot by Van den Leyden. It presents "the concrete physical space" that is filled with everything that is unspeakable with words. An implied incest that belongs to the material realm coexists with "the crackling, nocturnal bombardment of shooting stars" that sounds revelatory, metaphysical or spiritual in the same painting (Artaud, 1958: 37, 34). The fusion of the sekala and the niskala in the painting sustains the organic creation that is what Artaud truly desires to see in the Western theatre which has deeply been infected with the dialogues. The Western theatre lacks in the physical language that can express everything theatrical (38). This mode of expression disenthralls the western theatre from the totalizing principles of speech, words. Thanks to this, as Murphy (2016) also mentions, the theatre will become the body without organs that can redeem itself from its automatic reflexes usually conveyed through the poisonous words (4).

Goodall (1987), an important critic on Artaud, states that Artaud finds Shakespeare as the prime culprit responsible for poisoning the western theatre with words (118). To Artaud, Shakespeare's bold use of the soliloquys, monologues, and dialogues in order to attempt to express the things that the human speech is incapable of has long infected the western theatre. Goodall (1987) also touches upon Artaud's similar attack on Shelley's addiction to words in his effort to express the theatrical scenes in his version of The Cenci (1819). Artaud (1970) in his short article on The Cenci compares Shelley's language to "a summer night bombarded by meteors" (Vii). The main point in Artaud's revision of The Cenci is Artaud's replacement of Shelley's aesthetic language with action. Artaud draws attention to Shelley's failure to express the theatrical events with his hyperbolic use of the aesthetic language. As Goodall (1987) well observes, in Shelley's version of Cenci, Beatrice's attempt to explain the inexplicability of the rape scene with "one hundred and seventy lines of perfect blank verse" might sound quite artificial for the audience since no one can expect such a flawless speech uttered by a traumatic person (122). Therefore, Artaud (1970) prefers to use a physical language that best expresses "the nature in the raw, [...], in the form of earth's volcanic eruptions" (Vii). What he means by the physical language is gestures, movements and sounds which can contribute to the meaning as much as human speech. The characters' "roaring, spinning around, flaunting their instincts or their vices creates a dream like state where "a sort of majestic fate vibrates" (Artaud, 1970: iX).

Artaud in his letter to Louis Jouvet gives some reasons to feature the mise en scene. He states that the human speech is insufficient to activate the pure forces of the unconscious (Blin et al., 1972: 95). In his The Theatre and Its Double, he boldly claims, "it is the mise en scene that is the theatre" (Artaud, 1958: 41). To Artaud, the mise en scene as "the pure theatrical language" can only reveal the suppressed forces of the unconscious. Through too much exposure to lighting, sound, gesture and text, Artaud's theatre aims to break the Selfdefense mechanism of the spectators in order to force them to participate in the action. He also appeals to such stunning effects to destroy the stereotypes in the western theatre.

With these purposes in mind, The Theatre of Cruelty, Artaud's innovative stage, performs the Cenci (1935) at the Folies-Wagram in Paris. His interview in Le Petit Parisien published on April 14, 1935 about The Cenci shows his clear expectation from the play. He says, "a subject that is barbaric, out of time" (98). Idzkowski, a critic from Le Jour reports, "this tragedy [the Cenci] contains all the drama of our epoch in miniature" (Blin

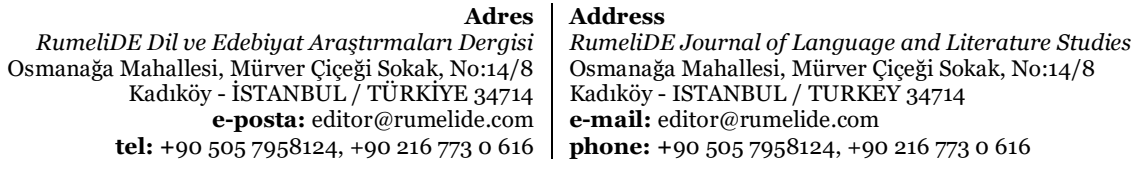


et al., 1972: 100). The critical reception of the Cenci is quite complicated. According to Curtin (2010), The Cenci was reviewed as a huge failure leading to Artaud's mental breakdown (250). Eugene Gegenbach in his letter to Artaud expresses the spectators' lunatic laugh during the performance and pities him saying "there is nothing more to be done for you" (Blin et al., 1972: 142). Gerald D'Houville from Le petit Parisien attacks the Cenci with these words:

Our ears tortured by deafening music produced by loudspeakers, [...], we were in a state of alert as if we were hearing the wail of sirens during an evening of 'air raids'. Without doubt, we were warned in this manner that this was an evening of massacres. But we resigned ourselves to it. (Blin et al., 1972: 135)

Unlike D'Houville and Gegenbach, Pierre-Jean Jouve, a friend of Artaud, praises The Cenci as an animistic play. He particularly extols Artaud's mise en scene with its extreme sound effects when combined with the dance performances of the characters (141). The negative reviews are rather nauseating for him. Artaud complains about the dishonesty of some reviewers towards The Cenci since they only came to see the failure of the play. Artaud in his interview in La Bete Noire (June 1,1935) accuses the French public of not being mature enough "for a feast of the Gods" (142). It is an evocation of the ancient ritualistic myths which are inherently cannibalistic. The cannibalistic acts such as human/animal sacrifices, parricide, infanticide, and fratricide are commonly seen in the ancient myths. They are inherently cruel, but these acts serve for a purpose in the myths. They are moved by the destructive instincts to give way to new creations. In other words, they are the prime movers of the Self-becoming since life itself, as Vork (2013) also states, "consumes to create or creates to consume" (308). It is the perpetual play between the destructive and creative forces. To give an example from an ancient Greek myth, one may refer to the myth of Kronos and Rhea. Kronos is a cruel father who swallows his own children as soon as they are born lest they should pose threats to his throne. This cannibalistic act will eventually lead to disgorging new deities. It is also the same for the next generation of Olympian Gods. Zeus resembles to his father, Kronos as soon as he supplants him. The cyclic relationship between the destructive and creative forces is a recurrent theme in the ancient myths. Similar to the ancient great myths, Artaud's The Cenci is inherently cruel, but it serves for a higher purpose not addressing to the conservative French public.

Cruelty for Artaud is a necessity for the Western theatre. He says, "Everything that acts is a cruelty" since life is a flux of energy without pattern or discourse (Artaud, 1958: 85). Therefore, it should have "nothing congealed" that can possibly impede it from turning into true act or magic (114). He argues that theatre's first mission is to prepare the audience about the possible fall of the sky (79). Consequently, as Artaud puts forth, the theatre of cruelty is bloody, but not systematically so. As opposed to the popular belief, the word, 'cruelty', as Artaud points out, does not necessarily mean bloodshed or sadism (102). Instead, cruelty is the necessary path to destroy the false shadows, submissive to the organs/institutions. It is the true path for Artaud to experience the totality of man. With this purpose, in the Theatre of Cruelty, the audience is located at the center, and the stage surrounds them. As mentioned above, Artaud aims to hypnotize the audience with the stunning effects of the mise en scence. The audience is resigned to the effects and eventually experiences the catharsis not through pity and fear but through terror and cruelty.

Artaud's The Cenci bears the characteristics of the Theatre of Cruelty. It seems to have been a deliberate design to implement his aesthetic of cruelty into action. The play is a severe attack on the Western rationality devoid of the spirit. Although the play is full of bloodshed, rape, murder, and chaos, particularly the protagonists, as Artaud emphasizes in his short article on The Cenci, act with the principle of amorality like the divine beings of the ancient myths. Their acts are beyond the norms of the society. Count Cenci's attitude well corroborates this point. He says, "For me, life, death, God, incest, repentance, crime do not exist.

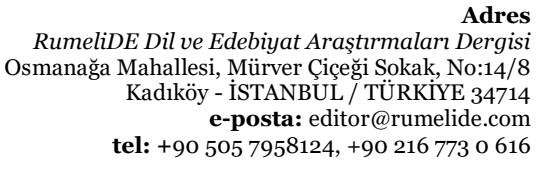

RumeliDE Dil ve Edebiyat Araşttrmaları Dergisi tel: +90 $5057958124,+902167730616$
Address

RumeliDE Journal of Language and Literature Studies

Osmanağa Mahallesi, Mürver Çiçeği Sokak, No:14/8

Kadıköy - ISTANBUL / TURKEY 34714

e-mail: editor@rumelide.com

phone: +90 5057958124, +90 2167730616 
I obey my own law" (Artaud, 1970: 8). People cannot be categorized as guilty or blameless according to Artaud. They act beyond the ethical boundaries of any kind of system.

Artaud in his letter to Andre Gide about The Cenci says, "In this play, nothing is treated with respect. I want to make everyone understand that I attack the social superstition of the family" (Blin et al., 1972, p.92). Artaud wants to prepare the audience for Count Cenci's cruel actions such as infanticide, rape, and torture of any kind. In Artaud's plan, Count Cenci seems to act like a scourge used for the dissolution of the corroded organs/values of the society. He is the destroyer of the worn-out codes of the family, society and religion. Goodall (1987) is quite right in her metaphorical comparison of Count Cenci to plague. She furthers her comparison of Beatrice, Lucretia and his sons to the victims of the plague (p.123). However outrageous his acts can be judged within any moral constraints, he is the only character that is true to his nature. He says, "I am a force of nature" (Artaud, 1970: 8). The play starts with the scene in which Camillo and Count Cenci talk over the murder committed by Cenci features the nakedness of Cenci in the face of the hypocrisy of the church. Here, Camillo is the mouthpiece of the corrupted church and he is the negotiator between Count Cenci and authority that exploits Cenci's richness by covering his guilt. Count Cenci who acts with the Dionysian force is not afraid of even the Pope. He starkly shows the true face of the church with these words: "This Pope is too greedy for riches. It has become too easy today for a man of power to bury his crimes under his piles of gold" (Artaud, 1970: 6). He attacks the church despite the fact that the church appeals to coverup for his evil motives, since the church is another corrosive institution like family that impedes the totality of man. He thinks of those institutions as wounds that corrupt everything.

Count Cenci is the embodiment of chaos. His energy is ready to blast like the eruption of volcano. This unrestrained energy manifests itself in the animalistic, brutal form in the play. As he questions, "how can I resist the forces burning within me, bursting out of me?" (8). This questioning is an indication of his selfdefense mechanism to justify his cruel acts rather than a quest for getting it under control. He desires to go back to man's primitive nature not governed by any restraining, poisonous codes of the civilized life. His destructive energy is firstly visible in the banquet scene where Count Cenci invites people to a party with an intention of giving some good news. To the shock and horror of the banquet guests, he raises his goblet to celebrate the deaths of his sons. Interestingly enough, in this scene as in many others, Artaud minimizes the use of the words for the maximum effect of the action on the audience. Artaud in the role of Count Cenci positions himself at the center while others are running around him. This whirlwind action in the scene is particularly highlighted to imply the chaotic nature of Count Cenci. His daughter, Beatrice, the main victim of the tragedy, is appalled by the bloody news, and screams locking the gates, "Do not leave us with this savage beast..." (Artaud, 1970: 16). As one can notice, Count Cenci is the mouthpiece of Artaud. He justifies his appeal to cruelty and tyranny, claiming, "I shall torture the soul by abusing the body: and when it is done as thoroughly as a living man can do it..." (Artaud, 1970: 9). Similarly, Artaud considers that the aesthetic of cruelty is the necessary tool to cleanse the infected soul.

Count Cenci undertakes the cleansing mission to bridge the gap between the theatre and the real life by torturing his family, the source of the infection. He wishes to massacre all of them but Bernardo, his little son. He wishes to spare him not because of showing mercy of him but because he wants him alive to witness and tell his story. Metaphorically speaking, he turns his house into the modern house of Atreus. Beatrice thinks of her father as "her unhappy fate" (Artaud, 1970: 10). In the romantic scene where Orsino expresses his love for Beatrice, she does not return his love, replying to him, "Because of [Count Cenci], I am no longer made for human love. Only in death can love become real for me" (Artaud, 1970: 11). Beatrice feels drawn to the grotesque world of Count Cenci whom she hates most. As some psychologists claim, one resembles the one that $\mathrm{s} /$ he hates most in life. The case of Beatrice exactly evidences it. This is what is truly desired by

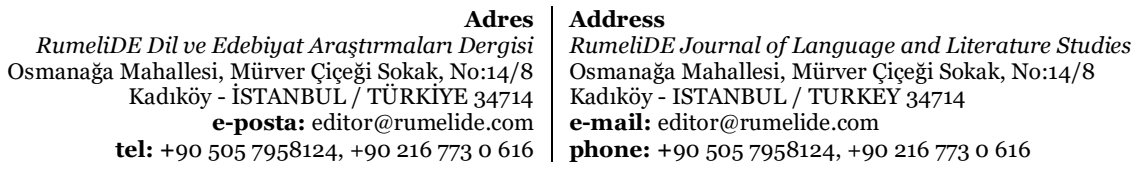


Count Cenci. He wishes to instill the seeds of evil into her. He believes that transforming his sole antagonist, his daughter, into an image of himself, will satisfy his desire. By raping his daughter, Cenci attempts to quench her 'light', 'warmth', 'brightness', which are identified with her. Before the rape, she is metaphorically compared to "doe" (22). After the rape, it is not surprising to hear her mention of the animal that "appears in her dreams". Most critics associate the animal with Count Cenci. They may be right in their context. However, there is another way to read it. Beatrice has already had it as a repressed force. It is released in her dreams. After the rape, it is unleashed by her vengeance. This animal symbolically represents the boundless energy which is destructive. This vile action surfaces the animalistic energy which is uncontrollable.

For the revenge, she hires two assassins to kill her father with the help of her family members. As Orsion says, "their mouths are sealed by nature" (36). It is important to mention that unlike the assassins in Shelley's version, Artaud intentionally mutes them since he aims to feature the significance of mimes, gestures as the alternative ways for communication to words. As Forbes (2015) rightly states, Artaud turns to mimetic theater that resists Shelley's "diegetic representation" (398). When we move back to our contextual discussion, one may notice that Beatrice hiring of the assassins is an implicit reference to her gradual transformation to become like her father. Her wrath swells when she interprets their mimes that express their failed attempt. She says:

You claim to be death-dealers, and yet you are so scared of an old man mouthing a discourse with his conscience in his dreams. Go up there and split his head in two or I shall kill him with whatever weapon comes to hand and then accuse you of his death. (Artaud, 1970: 42)

Upon seeing Beatrice' fury, they screw up their courage and managed to kill him in their second attempt. Beatrice' becoming of her father cannot escape from the eyes of a careful spectator. The line between the killer and the victim gets blurred. Beatrice says, "For I fear that death may teach me that I have ended by resembling him" (Artaud, 1970: 52). Forbes (2015) is quite right in his reference to Ferenczi's argument that the victim defends oneself by unconsciously imitating the attacker (400). The repressed beast surfaces in the place of her father by resigning to him.

Beatrice suffers from a heavy punishment upon parricide by the Christian authority. The torturing machine is highly interesting to note. Beatrice is tied to a turning wheel. She is forced to confess the crime. However, "she denies guilt" (Artaud, 1970: 49). She has lost her belief in the justice of the Christian institution. She utters some similar words like her father. She says, "From now on I can believe only in the justice I myself shall choose" (Artaud, 1970: 34). Beatrice on the turning wheel who seems to give the impression of dancing embraces the fatal consequences of her unhappy fortune. The spectators hypnotized by the scene and Beatrice' screams of pain echoed by the loudspeakers experience the feelings of terror and awe. Beatrice's destruction engenders a great awakening of the spectators towards the rotten values surrounding them. This is why Artaud argues that cruelty fed by the "refined crime" will cleanse the consciousness of the spectators from the poisoned codes, which will eventually restore the balance between theatre and the real life. To conclude, Artaud's The Cenci is a quest for the ritualistic drama which casts some magic over the spectators, thanks to which they are carried to an anarchic state where they can achieve the totality of man fed by the unrestrained energy. For Artaud, this will only bring the worn-out Western theatre back to its ritual cycle.

\section{References}

Artaud, A. (1970). The Cenci. Grove Press, Inc., New York, First Evergreen Edition.

Artaud, A. (1958). The Theater and Its Double. Grove Press 841 Broadway New York, NY 10003.

Adres | Address

RumeliDE Dil ve Edebiyat Araşturmalar Dergisi $\quad$ RumeliDE Journal of Language and Literature Studies

Osmanağa Mahallesi, Mürver Çiçeği Sokak, No:14/8 Osmanağa Mahallesi, Mürver Çiçeği Sokak, No:14/8

Kadıköy - ÍSTANBUL / TÜRKIYE 34714 Kadıköy - ISTANBUL / TURKEY 34714

e-posta: editor@rumelide.com e-mail: editor@rumelide.com

tel: +90 505 7958124, +90 2167730616 phone: +90 505 7958124, +90 2167730616 
Blin, R. ; Artaud, A., Kirby, V. N., Nes, N. E., \& Robbins, A. (1972). Antonin Artaud in" Les Cenci". The Drama Review: TDR, 91-145.

Clancy, P. (1985). Artaud and the Balinese theatre. Modern drama, 28(3), 397-412.

Curtin, A. (2010). Cruel Vibrations: Sounding Out Antonin Artaud's Production of Les Cenci1. Theatre Research International, 35(3), 250-262.

DK. (2018). The Mythology Book: Big Ideas Simply Explained.

Ferenczi, S. (1995). The clinical diary of Sándor Ferenczi. Harvard University Press.

Forbes, A. (2015). Return of the Cenci: Theaters of Trauma in Shelley and Artaud. Comparative Literature, 67(4), 394-414.

Goodall, J. (1987). Artaud's revision of Shelley's The Cenci: the text and its double. Comparative drama, 21(2), 115-126.

Murphy, J. (2016). Artaud's Metamorphosis: From Hieroglyphs to Bodies Without Organs. Pavement Books.

Palermo, C. (2007). Towards the embodiment of the mask Balinese topeng in contemporary practice (Doctoral dissertation, University of Tasmania).

Vork, R. (2013). Things that no one can say: The unspeakable act in Artaud's Les Cenci. Modern Drama, 56(3), 306-326.

Adres
RumeliDE Dil ve Edebiyat Araştırmaları Dergisi Osmanağa Mahallesi, Mürver Çiçeği Sokak, No:14/8 Kadıköy - İSTANBUL / TÜRKIYE 34714 e-posta: editor@rumelide.com tel: +90 $5057958124,+902167730616$
Address

RumeliDE Journal of Language and Literature Studies Osmanağa Mahallesi, Mürver Çiçeği Sokak, No:14/8

Kadıköy - ISTANBUL / TURKEY 34714

e-mail: editor@rumelide.com

phone: +90 $5057958124,+902167730616$ 